\title{
PENYELESAIAN SENGKETA PENGELOLAAN MAKAM SUNAN MURIA
}

\author{
Jagi Riatmo, Sukirno \\ Program Studi Magister Kenotariatan, \\ Fakultas Hukum, Universitas Diponegoro \\ Email: jagi@gmail.com
}

\begin{abstract}
Horizontal conflict often occurs in people who have different interests. What often happens is a dispute over land ownership rights. But there are also conflicts in the form of tomb management disputes. As happened in the Tomb of Sunan Muria which is located in Colo Village, Dawe District, Kudus Regency. This study discusses how to settle cases before entering the judicial domain and after decisions from a number of levels of justice and whether the decision is in accordance with applicable regulations to the extent to which the local government acts on the case. This study uses a descriptive qualitative research method with a sociological juridical approach. Data collection is done by collecting data sources both primary and secondary data, which are adjusted to the research. The absence of enforcement of regulations on Cultural Heritage Objects. In each case, the court has not fully considered social factors and historical factors, it is seen that in terms of management of the object of the family dispute the caretaker is not involved at all.
\end{abstract}

Keywords: Dispute Resolution, Management, Tomb of Sunan Muria

\begin{abstract}
Abstrak
Konflik horizontal sering terjadi pada masyarakat yang mempunyai kepentingan berbeda-beda. Yang sering terjadi ialah sengketa perselisihan kepemilikan hak atas tanah. Namun terdapat pula konflik yang berupa sengketa pengelolaan makam. Seperti yang terjadi pada Makam Sunan Muria yang terletak di Desa Colo Kecamatan Dawe Kabupaten Kudus. Penelitian ini membahas bagaimana penyelesaian kasus sebelum masuk pada ranah peradilan maupun setelah adanya putusan dari sejumlah tingkat peradilan.serta apakah putusan tersebut telah sesuai dengan peraturan yang berlaku hingga sejauh mana PEMDA setempat bertindak atas kasus tersebut. Penelitian ini menggunakan metode penelitian deskriptif kualitatif dengan dilakukan pendekatan yuridis sosiologis. Pengumpulan data dilakukan dengan mengumpulkan sumber data baik data primer dan sekunder, yang disesuaikan dengan penelitian. Belum adanya penegakan terhadap peraturan tentang Benda Cagar Budaya. Dalam setiap putusanya, pengadilan belum sepenuhnya mempertimbangkan faktor sosial dan faktor historis, hal tersebut terlihat bahwa dalam hal pengelolaan atas objek sengketa pihak keluarga juru kunci sama sekali tidak dilibatkan.
\end{abstract}

Kata Kunci : Penyelesaian Sengketa, Pengelolaan, Makam Sunan Muria 


\section{A. Pendahuluan}

Tanah adalah karunia Tuhan Yang Maha Esa kepada umat manusia di muka bumi. Tanah merupakan faktor penting dan merupakan fondasi utama dari semua kegiatan yang dilakukan bagi kelangsungan hidup manusia. Tanah bukan saja berfungsi sebagai tempat berdiam, mendirikan bangunan diatasnya berupa rumah, sarana sekolah, sarana tempat ibadah dan tempat berusaha, tetapi juga merupakan sumber kekuasaan dan jaminan hidup suatu bangsa.Tanah merupakan kebutuhan hidup manusia yang sangat mendasar. Saat meninggal dunia juga masih memerlukan tanah untuk penguburannya. Begitu pentingnya tanah sehingga setiap orang berusaha untuk menguasai dan memilikinya. Dengan begitu besarnya fungsi tanah bagi kehidupan manusia sering terjadi konflik antar individu.

Di Negara Indonesia fungsi tanah semakin meningkat dan mempunyai nilai ekonomis yang sangat tinggi, dari sekian banyak bidang yang menyangkut tanah, bidang ekonomi tampak mendominasi aktifitas manusia, dimana pertumbuhan penduduk serta pertumbuhan ekonomi yang melaju pesat. Sering kali karena pentingnya peran tanah dalam kehidupan manusia, tanah menjadi objek yang rawan terhadap perselisihan atau sengketa antar manusia. Hal ini terjadi karena kebutuhan manusia akan tanah semakin meningkat, namun persediaan tanah relatif tetap. Sengketa tanah dalam masyarakat setiap tahun semakin meningkat dan terjadi hampir di seluruh daerah di Indonesia, baik perkotaan maupun di perdesaan. Dalam ranah hukum, dapat dikatakan bahwa sengketa adalah masalah antara dua orang atau lebih dimana keduanya saling mempermasalahkan suatu objek tertentu. Hal ini terjadi dikarenakan kesalahpahaman atau perbedaan pendapat atau persepsi antara keduanya yang kemudian menimbulkan akibat hukum bagi keduanya.

Konflik dilatarbelakangi oleh perberdaan ciri-ciri yang dibawa individu dalam suatu interaksi. Perbedaan-perbedaan tersebut diantaranya adalah menyangkut ciri fisik, kepandaian, pengetahuan, adat istiadat, keyakinan, dan lain sebagainya, dengan dibawa sertanya ciri-ciri individual dalam interaksi sosial, konflik merupakan situasi yang wajar dalam setiap masyarakat. Konflik hanya akan hilang bersamaan dengan hilangnya masyarakat itu sendiri. Konflik bertentangan dengan integrasi, sebaliknya integrasi yang tidak sempurna dapat menciptakan konflik.

Konflik horizontal sering terjadi pada masyarakat yang mempunyai kepentingan berbeda-beda. Yang sering terjadi ialah sengketa perselisihan kepemilikan hak atas tanah. Namun terdapat pula konflik yang berupa sengketa pengelolaan makam. Seperti yang terjadi pada Makam Sunan Muria yang terletak di Desa Colo Kecamatan Dawe Kabupaten Kudus. 
Konflik tersebut dilatar belakangi perselisihan antara pihak juru kunci yang sah dan mendapat hak pengelolaan atas makam Sunan Muria dengan pihak Tim Reformasi 17 yang berupaya mengelola makam tersebut. Bahkan kedua pihak tersebut masih terdapat hubungan darah.

Sengketa tersebut terjadi pada akhir tahun 90an tepatnya tahun 1998 hingga awal tahun 2000an. Pihak keluarga Kartodirono selaku juru kunci yang sah mendapatkan protes dari pihak Tim Reformasi atas posisi juru kunci tersebut. Mereka menghendaki juru kunci tersebut untuk diganti. Sengketa pun terjadi berlarut-larut, hingga dilakukan mediasi. Namun upaya mediasi tidak menyelesaikan masalah karena salah satu pihak mengingkari kesepakatan mediasi tersebut.Pihak Keluarga Kartodironomerasa tidak mendapatkan haknya, maka mereka mencoba menempuh jalur hukum. Keluarga Kartodirono (keluarga Juru Kunci yang sah) tetap berupaya menjalani semua proses hukum yang dapat dilakukan. Karena pada dasarnya keluarga Kartodirono lah yang berhak mendapatkan hak pengelolaan atas makam tersebut.

Sengketa tersebut telah menjalani proses hukum dari mulai pada tahap Pengadilan Negeri Kudus, Pengadilan Tinggi Semarang hingga Makamah Agung. Pada tahap Gugatan di tingakat pertama yang dilakukan di Pengadilan Negeri Kudus dimenangkan oleh pihak yang berhak atau pihak Keluarga Kartodirono. Namun pada tahap banding yang dilaksanakan di Pengadilan Tinggi Semarang selanjutnya dimenangkan oleh pihak yang berupaya mengelola atau pihak Tim Reformasi. Setelah itu upaya Kasasi dilakukan oleh pihak keluarga Kartodirono namun ditolak oleh Makamah Agung.

\section{B. Metode Penelitian}

Metode penelitian yang digunakan adalah analisa deskriptif kualitatif yaitu pengolahan data yang didasarkan pada hasil studi lapangan yang kemudian dipadukan dengan data yang diperoleh dari studi kepustakaan, sehingga nantinya diperoleh data yang akurat sedangkan terhadap permasalahan- nya dilakukan pendekatan yuridis sosiologis.(Soetandyo Wignyosubroto, 2002)

Pendekatan yuridis sosiologis, yaitu di dalam menghadapi permasalahan yang dibahas bedasarkan peraturan-peraturan yang berlaku kemudian dihubungkan dengan kenyataankenyataan yang terjadi dalam masyarakat.

Penulis mendapatkan data yang akurat dan otentik karena dilakukan dengan mengumpulkan sumber data baik data primer dan sekunder, yang disesuaikan dengan penelitian. Teknik 
pengumpulan data primer dan data sekunder yang digunakan adalah wawancara.(Amirudin, 2002)

Wawancara adalah situasi peran antara pribadi bertatap muka, ketka seseorang yakni pewawancara mengajukan pertanyaan-pertanyaan yang dirancang untuk memperoleh jawaban yang relevan dengan masalah penelitian kepada responden.(Soekanto, 1986) Wawancara langsung dalam pengumpulan faktasosial sebagai bahan kajian ilmu hukum empiris, dilakuakn dengan cara tanya jawab secara langsung dimana semua pertanyaan disusun secara sistematis, jelas dan terarah sesuai dengan isu hukum yang diangkat penulis. Wawancara tersebut semua keterangan yang diperoleh mengenai apa yang diinginkan dicatat dengan baik.(Bahder JOhan Nasotion, 2010)

Teknik dokumentasi adalah teknik pengumpulan data yang berwujud sumber data tertulis atau gambar. Sumber tertulis atau gambar berbentuk dokumen resmi, buku, majalah, arsip, dokumen pribadi, dan foto terkait dengan permasalahan penelitian.(Sudarto, 2002) Dilakukan untuk memperoleh dan memahami konsep dan teori serta ketentuan tentang perlindungan hukum terhadap pengelolaan Makam Sunan Muria.

Suatu penelitian pasti membutuhkan data yang lengkap dalam hal dimaksudkan agardata yang terkumpul benar-benar memiliki nilai validitas dan reabilitasyang cukup tinggi.Di dalam penelitian, lazimnya dikenal paling sedikit tiga jenis teknik pengumpulan data,yaitu : studi dokumen atau bahan pustaka, pengamatan atau observasi, dan wawancara atauinterview(Soekanto, 1986).Mengingat jenis data yang digunakan dalam penelitian ini adalah berupa jenis data sekunder yang diperoleh dari bahan pustaka, maka teknik pengumpulan data yang tepat yang digunakan dalam penelitian ini adalah studi kepustakaan, berupa pendapat ahli, tulisan dan buku-buku ilmiah dan bahan kepustakaan lainnya yang ada kaitannya dengan masalah penelitian ini.

Studi Dokumen berfungsi untuk mendukung dan menambah bukti dari sumber-sumber lain. Dalam penulisan ini khususnya untuk menggali asas-asas hukum dan kaidah-kaidah hukum, khususnya di bidang sengketa pengelolaan, penulis selain banyak mengkaji dari beberapa buku-buku, tulisan, juga menganalisa terhadap putusan-putusan Pengadilan atas sengketa-sengketa pengelolaan khususnya berkaitan dengan pengelolaan Makam Sunan Muria.

\section{Hasil dan Pembahasan}




\section{Duduk Permasalahan dan Proses penyelesaian sengketa sebelum diajukan ke Pengadilan.}

Pada sekitaran bulan Juli 1998 team "REFORMASI 17" atau tim 17 beserta masa menduduki dengan paksa Kawasan Makam Suanan Muria. Gerakan tersebut diketuai Garno Sunarno. Mereka menuntut ${ }^{1}$;

a) Menyerahkan Pengelolaan Makam Sunan Muria Kepada Pemerintah desa Colo.

b) Mempertanggungjawab-kan segala kegiatan dan tindakan dalam pengelolaan Makam yang selama ini dilakukan dengan tanpa melibatkan Pemerintah Desa Colo.

Mereka beranggapan bahwa pengurusan makam selama ini salah dan ingin menggantikan posisi pengelola.

\section{Mediasi}

Upaya penyelesaian yang pertama diadakan tanggal 24 Juli 1998. Pihak mediator ditengahi oleh mantan Kepala Desa Colo dan Kyai Desa Colo. Pertemuan tersebut hanya dihadiri oleh Tim 17. Dalam pertemuan tersebut, Tim17menghendaki penggantian pengurusan oleh juru kunci.

Proses mediasi yang kedua diadakan pada tanggal 26 Juli 1998 dengan mediator yang sama.Masing-masing perwakilan kedua pihak bertemu. Pada pertemuan tersebut, mediator memberikan saran berupa pembentukan yayasan oleh Tim 17. Tim 17 menghendaki membuat yayasan yang dibawahnya terdiri dari pengurusan keluarga Juru Kunci. Pihak Juru Kunci keberatan atas tuntutan tersebut karena yayasan dibuat oleh tim 17. Sedangkan keluarga Juru kunci menginginkan yayasan dibentuk sendiri oleh Keluarga Juru Kunci.

Upaya ketiga dimediasi oleh Asisten Tata Praja, Humas PEMDA, Kabag Hukum PEMDA, Wakil Camat Dawe dan Kepala Desa Colo. Pertemuan tersebut dihadiri oleh kedua belah pihak. Dari Keluarga Juru Kunci meminta agar pengelolaan atas makam dikembalikan. Tim 17 pun tidak setuju bahkan akan mempensiunkan Juru Kunci dan tidak mengikutsertakan Keluarga Juru Kunci dalam pengurusan Yayasan.

Pada 15 November 1998 Bupati kudus meminta sosok pemilik Pabrik Rokok Sukun bapak Rindho Wartono (almarhum) untuk dimintai bantuannya mendamaikan para pihak yang bersengketa dalam perebutan pengelolaan Makam Sunan Muria antara Keluarga Juru Kunci R. Kartodirono dengan Team $17^{2}$. Penyelesaian perkara tersebut diadakan di

\footnotetext{
${ }^{1}$ Porposal Tuntutan Tim Reformasi tgl 23 Juli 1998 oleh tim 17

${ }^{2}$ Penjelasan oleh sekretaris Alm bapak Rindho Wartono (Direktur PR Sukun Grup selaku mediator)
} 
rumah bapak Rindho Wartono di Gebog Kudus. Pada pertemuan pertama tersebut kedua belah pihak telah saling menerima dan mengakui serta menghormati bahwa $\mathrm{R}$. Kartodirono adalah Juru Kunci Makam Sunan Muria, oleh karena itu dibentuklah tim kecil untuk menyelesaikan sengketa tersebut. Setelah itu pertemuan dijadwalkan kembali tanggal 20 November 1998.

Pada 20 November 1998 diadakan pertemuan kedua. Bapak Rindho Wartono diwakili oleh sekretarisnya untuk melanjutkan proses mediasi yang diadakan di Desa Colo. Kedua belah pihak hadir dalam pertemuan tersebut, namun belum tercapai kesepakatan.

Pada 23 November 1998 diadakan pertemuan lagi antar kedua belah pihak yang bersengketa bertempat di Villa Sukun Desa Colo dengan ditengahi sekretaris Bapak Rindho Wartono bernama Alwi Tohir dan Lukman (almarhum). Pihak keluarga Juru Kunci Makam dihadiri oleh mbah R. Kartodirono dengan tiga putranya, sedangkan team 17 dihadiri oleh seluruh anggotanya yang berjumlah 17 orang. Dalam pertemuan tersebut telah disepakati :

a) Juru Kunci Makam Sunan Muria dikembalikan lagi kepada mbah R. Kartodirono, hanya tentang penyerahan kunci makam, namun salah satu pihak tim 17 tidak menghendaki penyerahan kunci makam pada rumah R.Katodirono. Pihak keluarga Juru kunci pun tidak mempermasalahkan tempat penyerahan kunci makam.

b) Penyerahan kunci makam disepakati akan dilakukan pada tanggal 5 Desember 1998, akan tetapi hal tersebut tidak dilakukan. Hingga tanggal 7 Desember 1998 Tim 17 mengirim surat pada pihak mediator bahwa pihaknya belum paham tentang penyerahan kunci makam dan tidak menyanggupi kesepakatan tersebut.

Pada 5 November 1998, pihak tim 17 membentuk yayasan Masjid/Makam Sunan Muria yang semakin memperkeruh proses mediasi. Pembentukan yayasan ${ }^{3}$ tersebut disetujui oleh Bupati Kudus yang notabene ikut memediasi para pihak. Dengan pengingkaran kesepakatan oleh tim 17 tersebut, pihak mediator mengundurkan diri dari penyelesaian sengketa dan membuat laporan kepada Bupati Kudus.

Jajaran Pemda, Polres, Kodim Kudus bersama ulama dan tokoh masyarakat pun pernah memediasi kedua belah pihak. Mereka hendak menindaklanjuti hasil musyawarah tertanggal 15 November 1998 yang disebutkan bawah tim 17 akan segera menyerahkan kunci makam kepada pihak Juru Kunci dan menginginkan dibentuknya Yayasan yang

\footnotetext{
${ }^{3}$ Akta Yayasan Masjid dan Makam Sunan Muria No. 30 tanggal 19 Agustus 1998.
} 
terdiri dari unsur Keluarga Juru Kunci, tim 17, dan Pemerintah Daerah. Namun tim 17 mengklaim bahwa tidak diperlukan pergantian pengurusan yayasan yang sudah dianggap baik dan mempersilahkan pihak keluarga juru kunci jika tidak terima dengan hal tersebut.

\section{Putusan Pengadilan belum sepenuhnya menerapkan Undang-undang yang berlaku.}

a) Putusan Pengadilan Negeri

Proses pengadilan kasus sengketa pengelolaan Makam Sunan Muria telah ditempuh setidaknya dengan 4 kali persidangan diantaranya pada Pengadilan Negeri Kudus, Pengadilan Tinggi Semarang, dan Mahkamah Agung RI. Pada Mahkamah Agung sendiri terdapat 2 kali putusan diantaranya putusan tingkat Kasasi dan Putusan Peninjauan Kembali.

Pada proses pengadilan pertama yaitu pada Pengadilan Negeri Kudus, yang bertindak sebagai Penguggat ialah pihak Keluarga Juru Kunci. Mereka merasa haknya telah direnggut oleh tim 17 secara melawan hukum. Dalam gugatanya, mereka menuntut agar pengelolaan atas Makam Sunan Muria dikembalikan. Hal tersebut didasari karena pada dasarnya pengelolaan Makam selama ini diwarisi secara turun-temurun dalam garis keturunan. Objek warisannya berupa komplek Makam dan Masjid yang telah dijelaskan sebelumnya.

Penguasaan Makam oleh tim 17 dinilai melanggar hukum. Terlihat bahwa ada upaya semacam reformasi oleh sekelompok orang. Upaya tersebut dilakukan dengan cara berdemo dan merebut dengan paksa kunci Makam. Cara pendudukan tersebutlah yang dituntut oleh keluarga Juru Kunci secara pidana dan perdata karena terdapat unsur ancaman dan paksaan.

Dalam sejarah pengelolaan nya, telah terdapat setidaknya 9 Juru Kunci Makam yang kesemuanya diangkat secara sah dan memiliki hubungan darah. Permasalahan timbul tentang tata cara pengangkatan Juru Kunci. Pihak tim 17 mengklaim bahwa Juru Kunci ditunjuk oleh seorang kepala desa. Sedangkan oleh keluarga Juru Kunci berpendapat bahwa penunjukan juru kunci dilakukan dengan sistem pewarisan. Hal tersebut menjadi masalah yang besar karena menyangkut sejarah dan kebiasaan adat setempat. Namum dalam pertimbangannya, Pengadilan Negeri tidak memepersalahkan tentang siapa yang berhak menunjuk atau mengangkat juru kunci 
karena Tim 17 juga mengakui bahwa R. Kartodirono ialah juru kunci makam ke-9 yang sah.

Pendirian Yayasan oleh tim 17 juga dipermasalahkan dalam gugatan. Hal tersebut dikarenakan pengatasnamaan sepihak atas Makam Sunan Muria dengan tidak melalui pertimbangan dan pengikutsertaan Juru Kunci Makam yang sah. Terlebih lagi keikutsertaan Bupati dalam pengurusan Yayasan. Seharusnya sebagai kepala daerah dituntut untuk bertindak sebagai penengah bukan memihak. Karena menurut Undang-undang no. 22 tahun 1999 tentang Pemerintah Daerah (sekarang diubah dengan Undang-undang no. 9 tahun 2015) pada saat itu dalam pasal 48 huruh a dan b ;Kepala Daerah dilarang :

a) turut serta dalam swasta-perusahaan, baik milik swasta maupun milik Negara Daerah, atau dalam yayasan bidang apapun juga;

b) membuat keputusan yang secara khusus memberikan keuntungan bagi dirinya, anggota keluarganya, kroninya, golongan tertentu, atau kelompok yang secara nyata merugikan kepentingan umum atau mendiskriminasikan warga dan golongan masyarakat lain;

Namun Pengadilan Negeri bukan pada kapasitasnya untuk memutus permasalahan tersebut. Penulis juga menyayangkan ikut campurnya kepala daerah maupun Pemda setempat dalam salah satu pihak. Karena pada dasarnya kepala daerah maupun pemerintah berkedudukan sebagai pihak yang bijaksana.

\section{b) Putusan Pengadilan Tinggi}

Selanjutnya pada tingkat banding pada Pengadilan Tinggi Semarang yang menjadi pemohon ialah pihak tim 17. Terdapat perkembangan baru mengenai status Makam dan Masjid Sunan Muria. Melalui Surat Menteri Pendidikan Nasional RI tertanggal 29 November 1999 No. 299/M/1999 bahwa Komplek Makam dan Masjid Sunan Muria ditetapkan sebagai Benda Cagar Budaya. Hal tersebut menjadi dasar hukum yang kuat untuk pihak tim 17 memenangkan tingkat banding. Sebaliknya pada pihak Keluarga Juru Kunci Makam merasa penetapan tersebut memberatkan karena pada dasarnya mereka tidak kuat secara dasar hukum dibanding tim 17 yang telah mempunyai badan hukum yayasan.

Dengan ditetapkannya status Benda Cagar Budaya, otomatis Makam dan Masjid Sunan Muria menjadi domain negara. Negara dalam hal ini dapat melimpahkan wewenang nya pada Pemerintah Daerah masing-masing daerah. Posisi daerah di Indonesia sangat krusial karena memiliki posisi yang tunggal dan clear, yaitu sebagai 
local-self govern-ment, atau yang sering dikenal dengan daerah otonom dan menggunakan asas penyelenggaraan pemerintahan desentralisasi.

Pihak yang berewenang menunjuk pengelola Benda Cagar Budaya ialah pemerintah daerah. Maka dari itu pemerintah daerah dituntut untuk mengetahui secara rinci sejarah pengelolaan benda cagar budaya tersebut. Pemda juga dituntut untuk netral jika terjadi sengketa. Namun hal tersebut tidak terjadi pada kasus sengketa pengelolaan Makam Sunan Muria karena kepala daerah dan Pemdanya turut serta pada salah satu pihak.

Pasal 4 Peraturan Pemerintah No. 10 tahun 1993 tentang Pelaksanaan Undangundang No. 2 tahun 1992 tentang Benda Cagar Budaya (sekarang diganti dengan Undang-undang No.11 tahun 2010 tentang Benda Cagar Budaya) dikatakan bahwa ;

1) Setiap orang dapat memiliki atau menguasai benda cagar budaya tertentu dengan tetap memperhatikan fungsi sosialnya.

2) Benda cagar budaya tertentu sebagaimana dimaksud dalam ayat (1) terdiri atas benda cagar budaya yang:

a) diperoleh dari keluarga secara turun temurun atau warisan; atau

b) jumlah untuk setiap jenisnya cukup banyak dan sebagian telah dimiliki oleh Negara.

Menurut pasal tersebut jelas bahwa benda cagar budaya dapat dikelola secara pribadi sepanjang tetap memperhatikan fungsi sosialnya. Pemerintah daerah seharusnya mudah saja menunjuk Juru Kunci makam sebelumnya sebagai pengelola Benda Cagar Budaya. Jika perlu PEMDA setempat juga mengarahkan Juru Kunci untuk segera membentuk yayasan agar dapat mengelola objek Benda Cagar Budaya dengan pertanggungjawaban secara hukum. Namun hal tersebut tidak dilakukan Pemda dan membuat suasana beberapa masyarakat desa Colo terbelah menjadi dua kubu yang bertentangan.

\section{c) Putusan Mahkamah Agung}

Pada tingkat Kasasi pihak Keluarga Juru Kunci mempermasalahkan penetapan status Benda Cagar Budaya atas Komplek Makam dan Masjid Sunan Muria. Dalam permohonan kasasinya mereka beranggapan bahwa tanah kawasan makam berstatus tanah adat. Awal mula dasar penetapan status benda cagar budaya ialah Surat Keterangan Kepala Desa Colo tanggal 21 Juli 1999 No. 156/18/VII/99 yang menyatakan bahwa tanah Makam dan Masjid Sunan Muria merupakan bekas hak Gouverment Ground. Penetapan tersebut memicu polemik karena pada tingkat 
Gugatan posisi Kepala Desa tersebut sebagai turut tergugat dimana ia berpihak pada tim 17.

Upaya terakhir ditempuh pihak Keluarga Juru Kunci lewat Peninjauan Kembali atas Putusan Mahkamah Agung RI no. 2805K/PDT/2001. Dalam permohonannya, pemohon merasa hakim pada tingkat Kasasi melakukan kekhilafan atau kekeliriuan yang nyata. Dimana mereka merasa bahwa yang berwenang menentukan status kepemilikan tanah Badan Pertanahan Nasional bukan Menteri Pendidikan.

Mengenai penetapan status Benda Cagar Budaya, penulis setuju bahwa jika penetapan tersebut bertujuan untuk melestarikan dan melindungi Makam Sunan Muria itu sendiri. Namun yang menjadi permasalahan ialah mengenai pengelola Objek sengketa tersebut.

Makhkamah Agung dalam pertimbangan hukumnya menggunakan Undangundang No. 2 tahun 1992 tentang Benda Cagar Budaya (UUCB) mengenai penetapan status benda cagar budaya, namun tidak diterapkan pula materi dalam UUCB untuk dasar pertimbangan tentang pengelolaan. Hal itulah yang mendasari penulis bahwa putusan MA belum sepenuhnya menerapkan UUCB sebagai dasar hukum.

\section{Simpulan}

1. Proses penyelesaian sengketa sebelum diajukan ke pengadilan adalah melalui proses mediasi. Upaya mediasi telah diupayakan untuk menyelesaikan sengketa yang terjadi atas pengelolaan Makam Sunan Muria. Menurut data yang diperoleh, setidaknya telah ada lima kali upaya mediasi. Dari kelima upaya mediasi tersebut tidak memberikan solusi yang maksimal. Pada mediasi keempat sempat ada kesepakatan antar kedua belah pihak. Mediasi tersebut dimediatori oleh salah satu tokoh masyarakat yang dimintai oleh pihak berwenang. Namun salah satu pihak mengingkari kesepakatan tersebut dengan alasan bahwa mereka tidak paham dengan kesepakatan yang disepakatinya. Keadaan semakin sulit karena ada keberpihakan Kepala Daerah maupun Pemda pada salah satu pihak.Putusan pengadilan sesuai data yang diperoleh dan dianalisa menunjukan belum adanya kesesuaian dengan perundang-undangan yang berlaku. Sesuai peraturan yang berlaku, kasus diproses pada Pengadilan Negeri Kudus. Pada proses tersebut pihak Juru Kunci kembali mendapatkan haknya. Sekitar tahun 1999, Makam dan Masjid Sunan Muria ditetapkan sebagai Benda Cagar Budaya. Kasus meningkat ke tingkat banding. Dalam putusan banding, Pengadilan Tinggi Semarang menggugurkan putusan tingkat PN dan menyerahkan pengelolaan pada tim 
17 (yayasan). Selanjutnya dalam upaya Kasasi dan Peninjauan Kembali yang dilakukan pihak Juru Kunci, ditolak oleh MA.

2. Pokok dari permasalahan tersebut ialah tentang siapa yang berhak mengelola dan status objek sengketa. Menurut penelitian, Makam Sunan Muria selama ini dikelola oleh Juru Kunci dan punggowo-punggowo. Pengelolaan tersebut diterima dengan cara penunjukan maupun pemberian secara turun-temurun (sistem waris).Mengenai status Benda Cagar Budaya, undang-undang telah mengisyaratkan bahwa Benda Cagar Budaya dapat dikelola maupun dikuasai oleh seseorang sepanjang memperhatikan fungsi sosial dan tidak melanggar norma hukum, dalam hal ini ialah seorang Juru Kunci. Namun dalam prateknya hal tersebut tidak dipertimbangkan oleh Hakim tingkat PT. Maka dari itu penulis dalam hal ini berkesimpulan bahwa putusan tingkat PT belum sesuai dengan peraturan yang berlaku.

\section{DAFTAR PUSTAKA}

Amirudin. (2002). Pengantar Metode Penelitian Hukum. Jakarta: PT.Raja Grafindo Persada.

Bahder JOhan Nasotion. (2010). Metode Penelitian Ilmu Hukum. Jakarta: Remaja Rosdakarya.

Soekanto, S. (1986). Pengantar Penelitian Hukum. Jakarta: UI Pres.

Soetandyo Wignyosubroto. (2002). Hukum,Paradigma Metode dan Dinamika Masalahnya. Jakarta.

Sudarto. (2002). Metode Penelitian Filsafat. Jakarta: PT.Raja Grafindo Persada.

Penjelasan oleh sekretaris Alm bapak Rindho Wartono (Direktur PR Sukun Grup selaku mediator)

Porposal Tuntutan Tim Reformasi tgl 23 Juli 1998 oleh tim 17 